\title{
A CASE REPORT ON LUDWIG'S ANGINA: AN ENT EMERGENCY
}

\author{
MAHEEN M ${ }^{1 *}$, ARYA GOPAKUMAR ${ }^{2}$, RINCY ANNAMMA PHILIP² ${ }^{2}$ ZACHARIAH THOMAS
}

${ }^{1}$ Department of ENT, SK Hospital, Thiruvananthapuram, Kerala, India. ${ }^{2}$ Department of Pharm.D, The Dale View College of Pharmacy and Research Centre, Thiruvananthapuram, Kerala, India. Email: drmaheen@gmail.com

Received: 21 January 2019, Revised and Accepted: 10 May 2019

ABSTRACT

Ludwig's angina is defined as a rapidly progressive cellulitis of the floor of the mouth which involves both the submandibular and sublingual spaces of the face. The presented case was a 78-year-old female patient with a history of tooth extraction. Based on the clinical symptoms and computed tomography scan, the patient was diagnosed with Ludwig's angina and was treated appropriately by antibiotics and steroids after emergency tracheostomy and airway management. Early diagnosis and proper management can limit the morbidity and mortality rate of Ludwig's angina

Keywords: Ludwig's angina, Odontogenic origin, Tracheostomy, Airway management, Antibiotics.

(C) 2019 The Authors. Published by Innovare Academic Sciences Pvt Ltd. This is an open access article under the CC BY license (http://creativecommons. org/licenses/by/4. 0/) DOI: http://dx.doi.org/10.22159/ajpcr.2019.v12i6.32726

\section{INTRODUCTION}

Ludwig's angina is diffuse cellulitis in the submandibular, sublingual, and submental spaces, characterized by its propensity to spread rapidly to the surrounding tissues which are a collection of pus in the center of a tooth. It is named after the Stuttgart physician Karl Friedrich Wilhelm von Ludwig, who first described the condition in 1836 [1].

The most common cause is infected lower molars or pericoronitis, which is mostly seen in practice. This occurs due to inflammation of the soft tissues surrounding the crown of a partially erupted tooth, most commonly the second or third molar [2]. The majority of the cases of Ludwig's angina are odontogenic in etiology, primarily resulting from infections of the second and third molars. The roots of these teeth penetrate the mylohyoid ridge such that any abscess, or dental infection, has direct access to the submaxillary space. Once infection develops, it spreads contiguously to the sublingual space. Infection can also spread contiguously to involve the pharyngomaxillary and retropharyngeal spaces, thereby encircling the airway $[1,3]$. Although odontogenic infections are the most common route for the introduction of bacteria into the submandibular space, various other factors can also lead to this condition. The major clinical presentations of Ludwig's angina include bilateral submandibular swelling, airway obstruction, and edematous tongue protrusion [4]. Physical examination of the head and neck shows submandibular swelling characterized as calloused and tense [5]. The neck under the chin and the floor of the mouth will be edematous and erythematous. The tongue will be enlarged due to swelling of the soft tissue underneath $[1,6]$.

Here, we have presented a case of an elderly woman with Ludwig angina which is odontogenic in origin.

\section{CASE REPORT}

A 78-year-old female patient was presented to the ENT department with complaints of severe throat pain, swelling of the jaw, and the neck which had started 2 days duration. Swelling increased suddenly to neck along with swallowing. She was also having breathing difficulty for 2 days. The patient had a history of lower jaw tooth extraction 6 years ago. The patient was not a known case of diabetes mellitus, systemic illness, and asthma. On examination, the patient was found to have brawny tender swelling over the right submandibular region, floor of the mouth was raised and elevated tongue posture with dysphagia. Acute respiratory distress, stridor and cyanosis were absent. On blood investigation, the total count $(20,500$ cells $/ \mathrm{cmm})$ and erythrocyte sedimentation rate $(58 \mathrm{~mm} / \mathrm{h})$ were higher. Computerized tomography scan neck plain and contrast showed local inflammatory swelling over the right submandibular gland and infiltration of the right pyriform sinus obstructing the airway and lumen to the size of $5 \mathrm{~mm}$. The above findings are consistent with Ludwig's angina possibly of odontogenic origin and the patient was referred for a dental consultation. After explaining the need for an emergency incision and drainage, informed consent was taken for tracheostomy. Along with incision and drainage of submandibular salivary gland abscess, emergency tracheostomy was done in the supine position with neck extended and a midline vertical incision was made which was deepened for separating the muscle layer. The airway management was done for preventing the respiratory distress. After surgery, the patient was put on intravenous injections of augmentin $1.2 \mathrm{~g}$, Metrogyl $500 \mathrm{mg}$, Pactiv $1 \mathrm{~g}$, Dexona $8 \mathrm{mg}$, Pantop $40 \mathrm{mg}$, betadine gargle, and nebulizer Levolin. The patient was discharged after 6 days along with oral preparations of augmentin, Metrogyl, Chymoral Forte, Dolo, Pantop, and betadine gargle; the patient was advised for bed rest with increased oral fluid intake and meticulous oral hygiene. Fucidin ointment for local application was advised at the time of review.

\section{DISCUSSION}

Ludwig's angina is a potentially lethal infection with a mortality of 8\% [7]. Ludwig's angina associated with deep neck infection is an emergency condition that leads to edema, distortion, and airway obstruction. Most of the cases are due to odontogenic origin. Other factors responsible for this condition include sickle cell disease, a compromised immune system, and trauma, tongue piercing, and idiopathic origin in children. Ludwig's angina begins as a mild infection and can rapidly progress to brawny bilateral induration of the upper neck with pain, trismus, fever, dysphagia, and tongue elevation. The main complication of Ludwig's angina is asphyxia caused by expanding edema of soft tissues of the neck [2]. Another common cause of death is the acute loss of airway during interventions to control the condition [8]. Airway management is the initial step in managing Ludwig's angina [7]. Tracheostomy is a much safer method than endotracheal intubation in preventing airway obstruction. Early antibiotic therapy is of critical importance for successful treatment.

The case presented was managed by early surgical intervention in an attempt to relieve the imminent respiratory obstruction. However, the submandibular incision and drainage procedure which were 
performed release pus and therefore helped to reduce the swelling and airway discomfort. The most imminent danger to the patient, that of respiratory obstruction, had not been averted and it was necessary to maintain an airway by leaving the cuffed endotracheal tube in situ and ventilating the patient. Treatment with high-dose steroids improved the mouth opening and airway obstruction by rapidly reducing edema. Along with steroids, high-dose intravenous antibiotic therapy with beta-lactam antibiotics and metronidazole is highly recommended [9].

Early recognition of Ludwig's angina is important for medical therapy and timely consultation of emergency and surgical services have great importance [8]. Antibiotic selection varies, although penicillin and metronidazole are frequently used [10]. If a dental infectious source or involvement of the parapharyngeal, retropharyngeal, or mediastinal spaces is found, immediate consultation with the relevant surgical services would be indicated. In the present case, a parenteral antibiotic was only prescribed due to local infections [2].

Possible complications of Ludwig's angina are airway obstruction, carotid arterial rupture or sheath abscess, thrombophlebitis of the internal jugular vein, mediastinitis, empyema, necrotizing fasciitis, pericardial effusion, osteomyelitis, aspiration pneumonia, and pleural effusion [7].

The emergency tracheostomy has been considered the "gold standard" of airway management in patients with deep neck infections, but it may be difficult or impossible in advanced cases of infection due to the position needed for tracheostomy [9].

\section{CONCLUSION}

Early diagnosis of Ludwig's angina is of great significance primarily in patients having airway obstruction. In this case, the patient was managed by securing airway followed by surgical drainage. Awake tracheostomy is the preferred method in airway management. Maintaining and securing the airway should be the primary goal in patients presented with Ludwig's angina. By recognizing the condition in the early stage and commencement of antibiotics and steroids will reduce the morbidity and mortality of the disease condition. Right intervention at the right time prevented the patient from further complications.

\section{AUTHORS' CONTRIBUTIONS}

Ludwig's angina is one of the serious conditions in ENT and head and neck surgery department and the patient develops acute airway problem and death in case early intervention not done.

\section{COMPETING INTERESTS}

Nil.

\section{REFERENCES}

1. Candamourty R, Venkatachalam S, Babu R, Kumar S. Ludwig's angina an emergency: A case report with literature review. J Nat Sci Biol Med 2012;3:206-8.

2. Simsek M, Yildiz E, Hamdi MA. Ludwig's angina: A case report. JBR J Interdiscip Med Dent Sci 2014;2:1-4.

3. Brook I. Microbiology and principles of antimicrobial therapy for head and neck infections. Infect Dis Clin North Am 2007;21:355-91.

4. Melo TA, Rücker T, Carmo MP, Irala LE, Salles AA. Ludwig's angina: Diagnosis and treatment. RSBO 2013;10:172-5.

5. Costain N, Marrie JT. Ludwig's angina. Am J Med 2011;124:115-7.

6. Gbolahan OO, Olowookere S, Aboderin A, Omopariola O. Ludwig's angina following self application of an acidic chemical. Ann Ib Postgrad Med 2012;10:34-7

7. Saifeldeen K, Evans R. Ludwig's angina. Emerg Med J 2004;21:242-3.

8. Pak S, Cha D, Meyer C, Dee C, Fershko A. Ludwig's angina. Cureus 2017;9:e1588.

9. Holland C S. The management of ludwig's angina. Br J Oral Surg 1975;13:153-9.

10. Kulkarni HA, Pai DS, Bhattarai B, Rao TS, Ambareesha M. Ludwig's angina and airway considerations: A case report. Cases J 2008;1:1-4. 